\title{
Magnetic Iron Oxide Nanoparticles Modified with Moringa Seed Proteins for Recovery of Precious Metal Ions
}

\author{
Marta 0. N. Amuanyena1, Martha Kandawa-Schulz², Habauka M. Kwaambwa ${ }^{1 *}$ \\ ${ }^{1}$ Faculty of Health and Applied Sciences, Namibia University of Science and Technology, Windhoek, Namibia \\ ${ }^{2}$ Department of Chemistry and Biochemistry, University of Namibia, Windhoek, Namibia \\ Email: ^hkwaambwa@nust.na
}

How to cite this paper: Amuanyena, M.O.N., Kandawa-Schulz, M. and Kwaambwa, H.M. (2019) Magnetic Iron Oxide Nanoparticles Modified with Moringa Seed Proteins for Recovery of Precious Metal Ions. Journal of Biomaterials and Nanobiotechnology, 10, 142-158.

https://doi.org/10.4236/jbnb.2019.102008

Received: February 28, 2019

Accepted: April 25, 2019

Published: April 28, 2019

Copyright $\odot 2019$ by author(s) and Scientific Research Publishing Inc. This work is licensed under the Creative Commons Attribution International License (CC BY 4.0).

http://creativecommons.org/licenses/by/4.0/

\begin{abstract}
Precious metals are highly demanded economic value metals that require to be recovered from industrial wastes and electronic used products (e-waste). They are such as gold (Au) as well as Platinum Group Metals (PGMs) for instance palladium $(\mathrm{Pd})$ and platinum $(\mathrm{Pt})$. The study was conducted to test the magnetic iron oxide nanoparticles modified with Moringa oleifera seed proteins as adsorbent for recovery of $\mathrm{Au}(\mathrm{III}), \mathrm{Pd}(\mathrm{II})$ and $\mathrm{Pt}(\mathrm{IV})$ from aqueous solutions. Different functional groups responsible for adsorption, morphology, thermal stability, and surface charges of the nanoparticles were characterized with FTIR, SEM, TGA and Zeta potential respectively. Batch adsorption method was used, and precious metal ions percentage recovery was measured using ICP-OES. The effects of $\mathrm{pH}$, initial adsorbate concentration, adsorption agitation time and adsorbent dosage were studied at room temperature of $25^{\circ} \mathrm{C}$. $\mathrm{Au}$ (III) yielded a maximal recovery of $99.8 \%$, followed by $\mathrm{Pt}(\mathrm{IV})$ with $87.7 \%$, then $\mathrm{Pd}(\mathrm{II})$ with $72.7 \%$ at a $\mathrm{pH} 2.5,10 \mathrm{mg} / \mathrm{L}$ initial adsorbate concentration, 120 minutes agitation time and $0.065 \mathrm{~g}$ adsorbent dosage. These results suggested that modified iron oxide nanoparticles were effective in selective recovery of the precious metal ions.
\end{abstract}

\section{Keywords}

Adsorbent, Adsorbate, Adsorption Isotherm, Moringa oleifera, Precious Metals, Seed Proteins Extract

\section{Introduction}

The mining industry has new challenges as many state-of-the-art technologies require precious metals such as gold $(\mathrm{Au})$ as well as Platinum Group Metals 
(PGMs) for instance palladium (Pd) and platinum (Pt) [1]-[7]. Platinum and palladium composed of rhodium $(\mathrm{Rh})$, iridium (Ir), ruthenium $(\mathrm{Ru})$ and osmium (Os) form up the PGM family. These precious metals possess peculiar physical and chemical characteristics that lead to their significant economic value. Many fields including dental industries, automobile, pharmaceuticals, ornament, jewelry, ornament, medicine and electronics, require these rare naturally occurring precious metals. This rise in demand thus increases the necessity to explore methods to recover them from electronic used products (e-waste) and industrial wastes. However, there are health concerns associated with these precious metal ions, for instance, consumption of contaminated food might lead to conditions such as liver damage, kidney failure among others [8]. Deadly effects are observed on plants, animals and human beings upon bioaccumulation of complexes of platinum ions [7]. Molecular structures of animals and human cells are reported to be negatively affected when gold ions are ingested [6]. Also, carcinogenic effects in plant roots and animals are diagnosed with palladium ions [6] [9]. In turn, the whole food chain is reported to be adversely affected as a result of these precious metal ions, hence making it critical to recover these metal ions from industrial effluent not only because of the rise in demand but also to mitigate the health effects associated with them.

The techniques used in recoveries of precious metals are for instance solid phase extraction, ion exchange, membrane filtration, liquid-liquid extraction, cementation, photocatalytic degradation and chemical precipitation [5] [8] [10]. Nevertheless, there are numerous impediments in applying some of them including excessive costs, poor recovery of precious metal ions and introducing added pollutants other than the ones in the original waste [10]. Among these techniques, solid phase extraction under which adsorption falls is still regarded as a cost-effective method for recovery of low concentrated precious metal from aqueous solutions [11] [12] [13]. Adsorption is referred to as a chemical and physical contact among adsorbent and adsorbate [13]. Adsorbate is defined as a chemical that attaches to the adsorbent which is a solid surface [14]. The magnetic solid phase extraction is the most widespread method that includes magnetic adsorbents in eliminating analytes from solutions [6].

The study was aimed at selective recovery of metal ions using magnetic iron oxide nanoparticles modified with Moringa oleifera proteins. The use of a natural adsorbent offers numerous advantages including substantial decrease in sludge volume, quick separation and improved efficiency since this is known to be entirely biodegradable and non-toxic [15] [16]. On the other hand, magnetic iron oxide nanoparticles $\left(\mathrm{Fe}_{3} \mathrm{O}_{4}\right)$ are commonly accessible compounds in nature that can also be easily produced in the laboratory, chemically and physically stable, environmentally harmless and biocompatible [17] [18]. Several studies have revealed that it is vital to coat magnetic iron oxide before and after synthesizing to provide stability, avoid oxidation, prevent harmful contaminants and reduce agglomeration in order to optimize their usage [6] [19]-[27]. It is therefore, 
against this background that the study aimed at utilizing magnetic iron oxide nanoparticles modified with Moringa seed proteins rather than the naked magnetic iron oxide nanoparticles to determine its effectiveness in selective recovery of $\mathrm{Au}(\mathrm{III}), \mathrm{Pd}(\mathrm{II})$ and $\mathrm{Pt}(\mathrm{IV})$ from aqueous solutions. The $\mathrm{pH}$, initial adsorbate concentration, adsorption agitation time and adsorbent dosage were the parameters used to study the adsorption behaviour of $\mathrm{Au}(\mathrm{III}), \mathrm{Pd}(\mathrm{II})$ and $\mathrm{Pt}(\mathrm{IV})$ on magnetic iron oxide nanoparticles modified with Moringa seed proteins.

\section{Materials and Methods}

\subsection{Chemicals and Reagents}

Reagents used throughout the study were either chemically pure or of analytical grade. Deionized water was obtained from a Rios - DI system supplied by Merck. Whatman No. 1 filter papers with a diameter of $90 \mathrm{~mm}$ manufactured by GE Healthcare company were used. Sodium hydroxide $(\mathrm{NaOH})$ was supplied by Skylabs. Sodium chloride was supplied by LD didactic in Germany. Gold (III) chloride by Sigma-Aldrich, platinum (IV) chloride and palladium (II) chloride by Alfa aesar. Ferric chloride $\left(\mathrm{FeCl}_{3} \cdot 6 \mathrm{H}_{2} \mathrm{O}\right)$ and hydrochloric acid $(\mathrm{HCl})$ were supplied by Merck, petroleum ether $\left(40^{\circ} \mathrm{C}-60^{\circ} \mathrm{C}\right)$ by Skychem, whereas ferrous chloride $\left(\mathrm{FeCl}_{2} \cdot 4 \mathrm{H}_{2} \mathrm{O}\right)$, acetone and ammonium sulphate were obtained from Promark Chemicals. Preswollen Carboxymethyl cellulose was supplied by Biophoretics (USA). Multielement precious metals standard was supplied by Perkin Elmer.

\subsection{Instrumentation}

The study was based on laboratory experiments, and the following techniques were utilized to characterize the modified iron oxide nanoparticles: The Perkin Elmer UATR spectrum two system Fourier transform Infrared (FTIR) spectrometer was utilized to evaluate the key functional groups present that are accountable for adsorption in the modified magnetic iron oxide nanoparticles. Q600 V20.9 Build 20 Thermogravimetric Analyser (TGA) and Differential Scanning Calorimeter (DSC) was used for the decomposition and thermal stability of the nanoparticles. The morphology of the synthesized nanoparticles was characterized with the Jeol JSM-6010PLUS/LA Scanning Electron Microscope (SEM) equipped with the Oxford X-ray energy dispersive spectroscope (EDS). The surface charge of the nanoparticles was measured with a nanoZetasizer (Nano Zs model) between pH 2-12. A permanent magnet was utilized to assess whether the nanoparticles produced were magnetic. Perkin Elmer Inductively Coupled Plasma-Optical Emission Spectrometer (ICP-OES) was used for quantitative determination of metals.

\subsection{Preparation of Adsorbent}

\subsubsection{Preparation of Moringa oleifera Seed Extract}

Samples of $M$. oleifera mature dry pods were collected from a tree in Cimbes- 
basia, Windhoek. The extraction of the protein was carried out using the method by Maikokera and Kwaambwa [28]. The seeds obtained from the pods were deshelled skinned and the kernels crushed using a pestle and mortar to obtain a powder. The seeds powder was defatted by mixing with $40^{\circ} \mathrm{C}-60^{\circ} \mathrm{C}$ petroleum ether using hot plate magnetic stirrer at a continuous speed for two hours followed by suction filtration. The presence of oil is known to reduce the effectiveness of metals recovery thus necessary to remove it [29] [30]. The powder obtained was then dried in open air. This powder was then continuously stirred in $1 \mathrm{M}$ potassium chloride for an hour followed by suction filtration to remove the bigger solid particles followed by gravity filtration to obtain a clear solution. Studies have demonstrated that coagulating component extracted from M. oleifera seeds is more efficient using salt solution than tap water [28] [31]. Ammonium sulphate was used to precipitate the proteins in the extract to saturation as a result of "salting out" effect. The precipitated protein was filtered using suction filtration after which it was then re-dissolved in distilled water and dialyzed using Sigma-Aldrich dialysis tubing cellulose membrane of $43 \mathrm{~mm}$ width. The carboxymethyl cellulose (CMC) resin was utilized to purify the protein solution. The sodium chloride $(1 \mathrm{M})$ was used to elute the protein. The eluted protein solution was the ndialyzed. The $-80^{\circ} \mathrm{C}$ Chris Alpha 1-2 LD plus freeze drier was used to freeze-dry the resulting protein solution. The protein powder obtained was kept in an airtight container until ready for use.

\subsubsection{Preparation of Modified Magnetic Iron Oxide Nanoparticles}

Magnetic iron oxide $\left(\mathrm{Fe}_{3} \mathrm{O}_{4}\right)$ nanoparticles were prepared by chemical co-precipitation of $\mathrm{Fe}^{3+}$ and $\mathrm{Fe}^{2+}$ ions [11] [18] [31] [32]. According to this method, the iron salts solution was prepared by mixing ferric chloride $\left(\mathrm{FeCl}_{3} \cdot 6 \mathrm{H}_{2} \mathrm{O}\right)$ and ferrous chloride $\left(\mathrm{FeCl}_{2} \cdot 4 \mathrm{H}_{2} \mathrm{O}\right)$ in a ratio of $2: 1$ in $20 \mathrm{~mL} 1 \%$ aqueous protein solution at room temperature and continuous stirring for 20 minutes. Sodium hydroxide $(8 \mathrm{M})$ solution was prepared in $1 \%$ aqueous protein solution under ice water and continuous stirring for 30 minutes at room temperature. The precipitation of magnetic iron oxide $\left(\mathrm{Fe}_{3} \mathrm{O}_{4}\right)$ nanoparticles was achieved by dropping the iron salts solution into the $\mathrm{NaOH}$ solution at room temperature while continuous stirring for an hour. The magnetic iron oxide nanoparticles obtained with Sodium hydroxide as a base is favoured as they are deemed to possess better magnetic properties [20]. The permanent magnet is utilized to separate the resulting black nanoparticles produced before pouring out the supernatant. Lastly, water and acetone are used to wash the nanoparticles. The obtained fine modified magnetic $\mathrm{Fe}_{3} \mathrm{O}_{4}$ nanoparticles were finally freeze-dried for 24 hours and stored in a an airtight vial ready for use.

\subsection{Batch Adsorption Studies}

Gold, palladium and platinum precious metal ions solutions were prepared as follows [33] [34]: The stock solutions (100 $\left.\mathrm{mg} \cdot \mathrm{L}^{-1}\right)$ of predefined quantities of respective metal chloride salts were dissolved in distilled water. The desired 
working concentrations were prepared by diluting the stock solutions. Diluted concentrations of $0.1 \mathrm{M} \mathrm{HCl}$ and $0.1 \mathrm{M} \mathrm{NaOH}$ were used to create acidic and basic environments as required, respectively. The batch experiments were conducted in $50 \mathrm{~mL}$ falcon tubes with the modified magnetic iron oxide nanoparticles and the mixture of $\mathrm{Au}(\mathrm{III}), \mathrm{Pd}(\mathrm{II})$ and $\mathrm{Pt}(\mathrm{IV})$ solution. The solution was agitated with a Stuart Scientific mechanical shaker at a speed of $150 \mathrm{rpm}$, allowed to settle overnight before filtration using gravity filtration (Whatmann filter paper No. 1). Perkin Elmer Optima 8000 ICP-OES was used to analyze the equilibrium metal ions concentrations. The experiments were conducted by varying various parameters namely: $\mathrm{pH}(1.5-2.5)$, initial adsorbate concentration $\left(10-100 \mathrm{mgL}^{-1}\right)$, adsorption agitation time (30 - 240 minutes) and adsorbent dosage (0.005 - $0.065 \mathrm{~g})$ to optimize them. The analysis was done in triplicate and the averages were reported.

The recovery efficiency $(R)$ was calculated using the equation [35]:

$$
\% R=\frac{C_{i}-C_{f}}{C_{i}} \times 100
$$

where, $C_{i}$ is the initial concentration, $C_{f}$ is the final concentration of the analyte, and $\% \mathrm{R}$ is the recovery percentage.

\section{Results and Discussion}

\subsection{Characterisation of Modified Magnetic Iron Oxide Nanoparticles}

\subsubsection{Fourier Transform Infrared Spectrometer (FTIR)}

The FTIR measurements were performed to identify the main functional groups of modified magnetic iron oxide nanoparticles to understand the mechanism for precious metal ions adsorption. The transmittance band ranging from $4000 \mathrm{~cm}^{-1}$ to $400 \mathrm{~cm}^{-1}$ was recorded for the FTIR spectra as depicted in Figure 1 and Figure 2 and summarized in Table 1. These results and a study by Araujo et al. [36] depicted that a band at $3281.9 \mathrm{~cm}^{-1}$ for $\mathrm{OH}$ could be as a result of proteins and fatty acids structures in Moringa seeds. In addition, the symmetrical and asymmetrical stretching of $\mathrm{C}-\mathrm{H}$ bond from the $-\mathrm{CH}_{2}$ group. The $\mathrm{OH}$ (alcohol, carboxylic acid) arises at $2942.6 \mathrm{~cm}^{-1}$ wavenumber. Furthermore, the frequencies $1648.4 \mathrm{~cm}^{-1}$ representing Amide I and $1544 \mathrm{~cm}^{-1}$ for Amide II are part of the bands shown in the spectrum. A study by Nermark [37] confirmed that that these amides largely arise from the amide bonds joining amino acids. The study also reveals that absorption at amide I and II yield to $\mathrm{C}=\mathrm{O}$ bond stretching vibrations and $\mathrm{N}-\mathrm{H}$ bond bending vibrations, respectively, and they are primarily allocated to the $\alpha$-helix of the secondary structure in a protein. This further confirms the protein structure in Moringa seeds. Similar functional groups were attained for M. oleifera seed pods and Sclerocarya birrea [35] and Plantago ovata seeds [38]. On the other hand, typical functional groups for iron oxide are depicted by absorption band at $3664.7 \mathrm{~cm}^{-1}$ that corresponds to the hydroxyl functional group and a band at $543.2 \mathrm{~cm}^{-1}$ that is assigned to $\mathrm{Fe}-\mathrm{O}$ (iron oxide) group 


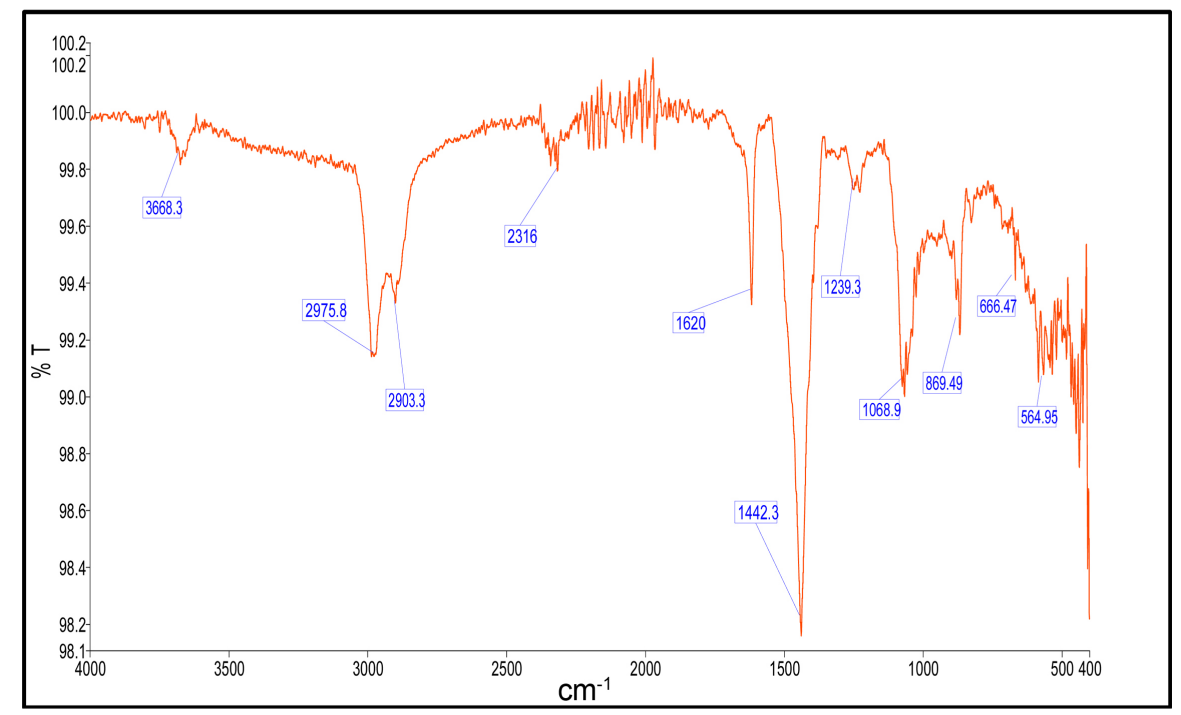

Figure 1. FTIR spectrum of unmodified magnetic iron oxide.

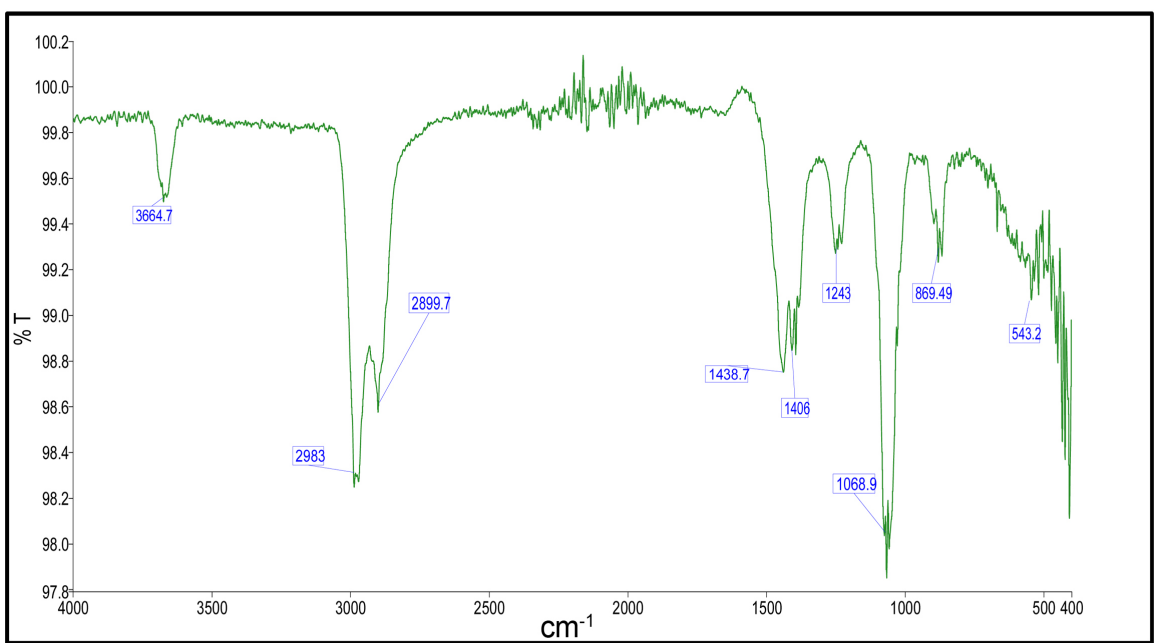

Figure 2. FTIR spectrum of iron oxide modified with Moringa seed proteins extract.

[39]. These identified functional groups might therefore explain the adsorption process thus recovery of precious metal ions in the current study.

\subsubsection{Scanning Electron Microscopy}

The surface morphology of the unmodified (left) and modified (right) magnetic iron oxide nanoparticles to understand the surface characteristics of the nanoparticles was studied using SEM as shown in Figure 3. The surface morphology is porous with various pore sizes as observed in the scanning electron micrograph and this might therefore facilitate the adsorption of the precious metal ions [35] [36]. As depicted in the micrographs, modified magnetic iron oxide nanoparticles appears to have better porosity in comparison to the unmodified magnetic iron oxide nanoparticles. However, the nanoparticles appear to have agglomerated and this might be due to strong bonding of nanoparticles, Van der Wall forces and magnetic dipoles [21] [42]. 

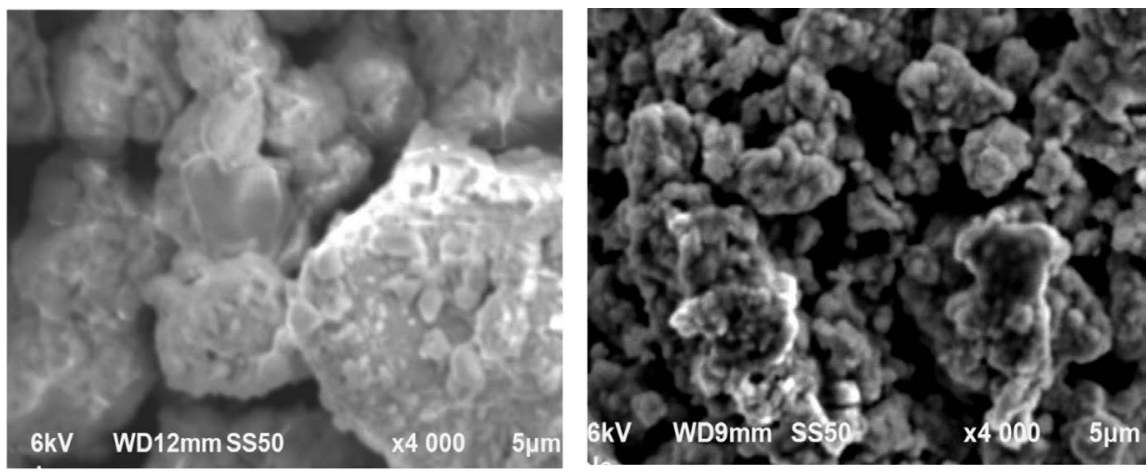

Figure 3. SEM unmodified and modified magnetic iron oxide nanoparticles.

Table 1. Analysis of the IR spectra for unmodified magnetic iron oxide nanoparticles and iron oxide modified with Moringa seed proteins extract $\left(\mathrm{MoFe}_{3} \mathrm{O}_{4}\right)$.

\begin{tabular}{|c|c|c|c|c|}
\hline Functional group & $\begin{array}{c}\text { Reference frequency } \\
\text { range }\left(\mathrm{cm}^{-1}\right) \\
{[35][36][39]-[44]}\end{array}$ & $\begin{array}{l}\text { Observed IR } \\
\text { frequency }\left(\mathrm{cm}^{-1}\right) \\
\text { for iron oxide }\end{array}$ & $\begin{array}{l}\text { IR frequency } \\
\left(\mathrm{cm}^{-1}\right) \text { for } \\
\mathrm{MoFe}_{3} \mathrm{O}_{4}\end{array}$ & $\begin{array}{l}\text { Peak shift } \\
\quad\left(\mathrm{cm}^{-1}\right)\end{array}$ \\
\hline $\mathrm{OH}$ stretching & $3700-3500$ & 3668.3 & 3664.7 & 3.6 \\
\hline $\mathrm{OH}$ (Alcohol) & $3400-2400$ & $\begin{array}{l}2903.3 \\
2975.8\end{array}$ & $\begin{array}{l}2899.7 \\
2983.3\end{array}$ & $\begin{array}{c}3.6 \\
-7.5\end{array}$ \\
\hline $\begin{array}{c}\text { OH bend } \\
\text { (Carboxylic acid) }\end{array}$ & $1440-1400$ & - & $\begin{array}{c}1438.7 \\
1406\end{array}$ & - \\
\hline $\begin{array}{c}\mathrm{H}-\mathrm{O}-\mathrm{H} \\
\text { (Adsorbed water) }\end{array}$ & $1652-1429$ & $\begin{array}{c}1442.3 \\
1620\end{array}$ & $\begin{array}{c}1438.7 \\
-\end{array}$ & 3.6 \\
\hline $\begin{array}{c}\text { CO stretching } \\
\text { (Carboxylic acid) }\end{array}$ & $1320-1210$ & - & 1243 & - \\
\hline $\begin{array}{l}\mathrm{OH} \text { stretching } \\
\text { vibration }\end{array}$ & $1092-1060$ & 1068.9 & 1068.9 & 0 \\
\hline $\begin{array}{l}\text { CO stretching } \\
\text { (Alcohol) }\end{array}$ & $1260-1000$ & 1239.3 & 1243 & -3.7 \\
\hline Alkenes ( $\mathrm{CH}$ bend) & $\sim 890$ & 889.49 & 869.49 & 20 \\
\hline Aromatics ( $\mathrm{CH}$ bend) & $\sim 880$ & 889.49 & 869.49 & 20 \\
\hline $\mathrm{Fe}-\mathrm{O}$ & $588-535$ & 564.95 & 543.2 & 21.75 \\
\hline
\end{tabular}

\subsubsection{Thermogravimetric Analysis}

Thermal stability of unmodified and modified magnetic iron oxide nanoparticles was studied when the nanoparticles were heated from $30.86^{\circ} \mathrm{C}$ to $794.80^{\circ} \mathrm{C}$ as shown in Figure 4 and Figure 5. The different thermal decomposition stages in terms of percentage weight loss and their respective derivatives weight loss percentage per ${ }^{\circ} \mathrm{C}$ were obtained [36]. The first stage between $30^{\circ} \mathrm{C}$ to $100^{\circ} \mathrm{C}$ is associated with water loss. The second stage ranging from $100^{\circ} \mathrm{C}$ to $350^{\circ} \mathrm{C}$ could be due to loss of organic matter that might include proteins amino acid residues with various functional groups and other low molecular weight compounds. The third stage between $350^{\circ} \mathrm{C}$ to $795^{\circ} \mathrm{C}$ might be from compounds with higher boiling point. At the end of the decomposition stage $\left(795^{\circ} \mathrm{C}\right)$, the total residue was therefore attained with overall weight loss of $17.7 \%$ and $17.2 \%$ for unmodified 


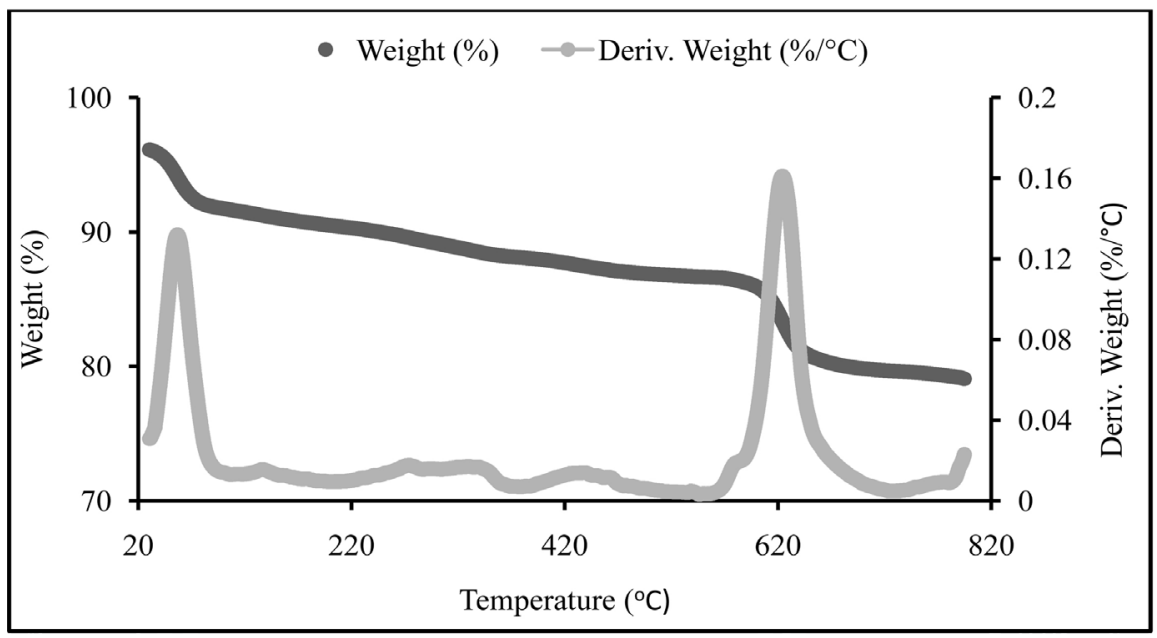

Figure 4. TGA curve for unmodified magnetic iron oxide nanoparticles with weight loss and derivative weight loss.

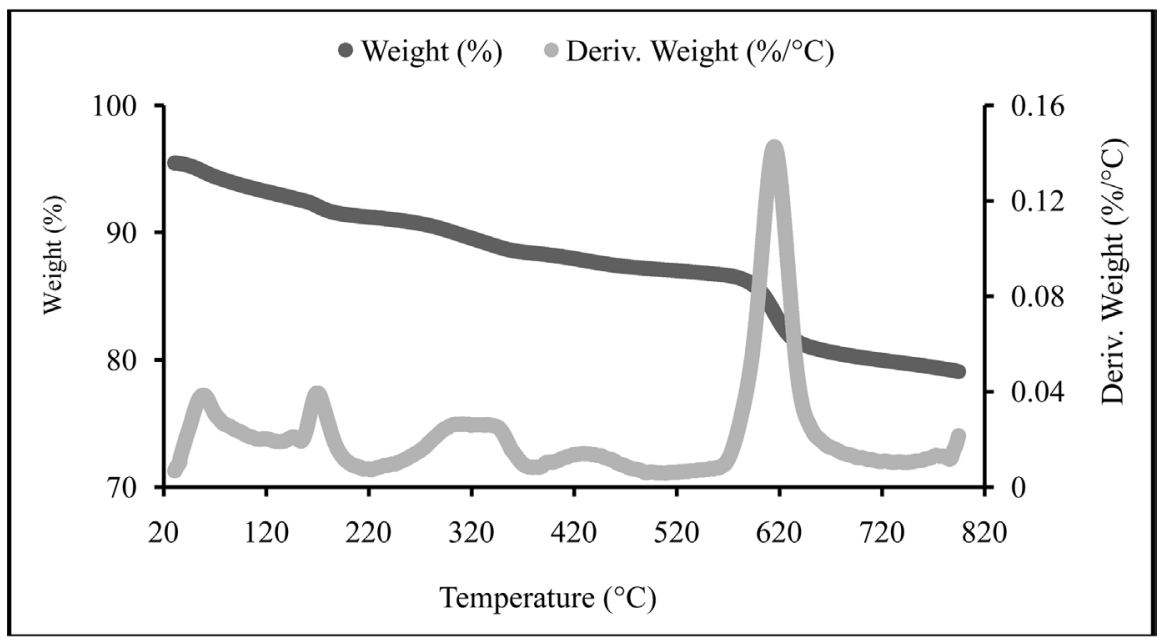

Figure 5. TGA curve for modified magnetic iron oxide nanoparticles with weight loss and derivative weight loss.

and modified iron oxide, respectively. As observed from the curves, the weight loss was slow and a study by Sneha and Sundaram [45] obtained a similar weight loss of about $17 \%$ on naked $\mathrm{Fe}_{3} \mathrm{O}_{4}$. Other studies by Padmavathy et al. [40] and Araujo et al. [36] also attained similar mass loss curve as in the current study.

\subsubsection{Zeta Potential}

The nanoZetasizer was used to characterize the surface charge of the unmodified and modified iron oxide nanoparticles in the $\mathrm{pH}$ range of 2 to 12 as shown in Figure 6. The zeta potential was $\mathrm{pH}$-dependent. The point of zero charge (isoelectric point) for modified iron oxide nanoparticles and unmodified iron oxide nanoparticles was found to 3.69 and 6.12, respectively. The curves show that at $\mathrm{pH}$ ranges below the isoelectric points of the nanoparticles, the surfaces are positively charged and negatively charged at $\mathrm{pH}$ ranges above the isoelectric points. The modified magnetic iron oxide nanoparticles is highly negatively 


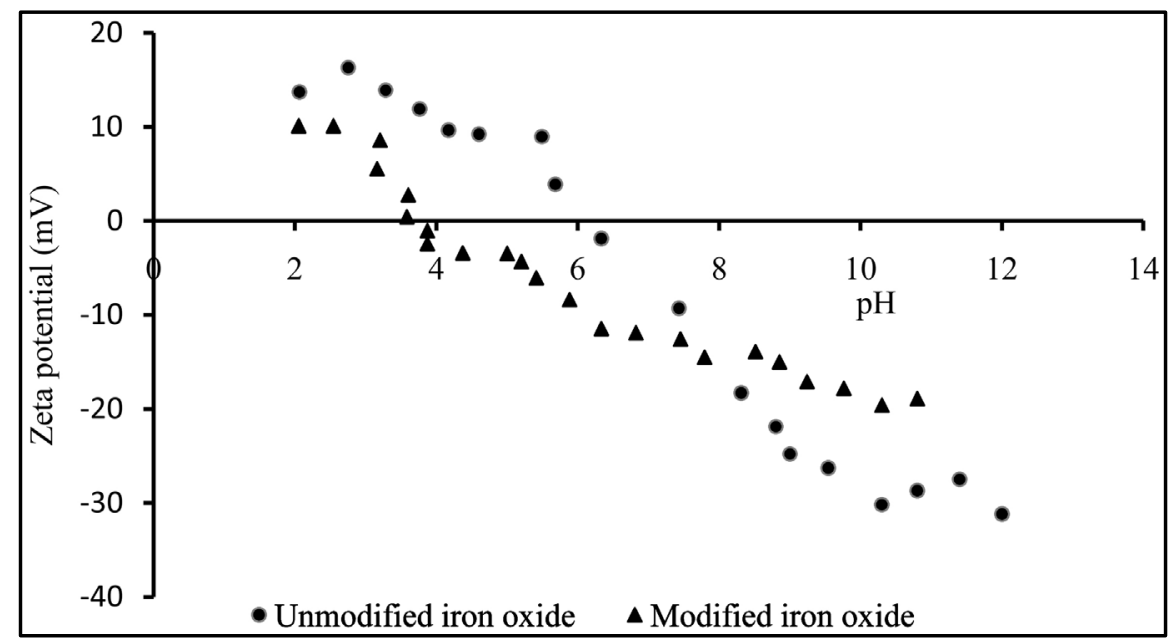

Figure 6. Zeta potential trends for unmodified and modified magnetic iron oxide nanoparticles.

charged, i.e. lower zeta potential, compared to unmodified magnetic iron oxide nanoparticles at high $\mathrm{pH}$ but less positively charged at lower $\mathrm{pH}$. Similar studies on the characterization of magnetic iron oxide by Aghaei et al. [6] and Yang et al. [20] obtained isoelectric points in the $\mathrm{pH}$ range of $6-7$ as well. In the current study, the surface charge values obtained therefore explain the dependency of adsorption on $\mathrm{pH}$ and the recovery of precious metal ions.

\subsection{Effect of Experimental Parameters on Adsorption of Precious Metal Ions on Modified Magnetic iron Oxide Nanoparticles}

\subsubsection{Effect of $\mathrm{pH}$}

The zeta potential of solid surface is an important factor to determine the electrostatic adsorption of metal ions onto the surface. The adsorption of precious metals ions from aqueous solutions is studied to be $\mathrm{pH}$ dependent [5] [43] [46] [47]. The selective recovery of precious metal ions on modified magnetic iron oxide nanoparticles was investigated in the $\mathrm{pH}$ range of 1.5 to 2.7 at constant agitation time of 120 minutes, $10 \mathrm{mg} / \mathrm{L}$ initial concentration and $0.065 \mathrm{~g}$ dosage. Several studies have suggested that adsorption of metal ions from wastewater is more efficient at low $\mathrm{pH}$ [38] [43] [46] [48]. The $\mathrm{pH}$ values were adjusted to desired values using $0.1 \mathrm{M} \mathrm{HCl}$. Figure 7 shows that as $\mathrm{pH}$ value increased, percentage recovery of precious metal ions increased until an optimal $\mathrm{pH}$ value is reached after which percentage recovery decreased. At $\mathrm{pH} 1.5$, percentage recovery of precious metal ions were $2.1 \%, 5.7 \%$ and $0.9 \%$ for $\mathrm{Au}(\mathrm{III}), \mathrm{Pt}(\mathrm{IV})$ and $\mathrm{Pd}(\mathrm{II})$, respectively. When compared to unmodified magnetic iron oxide nanoparticles, the values of $2.1 \%, 3.8 \%$ and $0 \%$ for $\mathrm{Au}(\mathrm{III}), \mathrm{Pt}(\mathrm{IV})$ and $\mathrm{Pd}(\mathrm{II})$, respectively, were obtained. These percentage recoveries increased to $99.8 \%$, $88.6 \%$ and $77.2 \%$ for $\mathrm{Au}(\mathrm{III}), \mathrm{Pt}(\mathrm{IV})$ and $\mathrm{Pd}(\mathrm{II})$, respectively, at $\mathrm{pH} 2.5$ which was taken to be optimal $\mathrm{pH}$ value. For unmodified magnetic iron oxide nanoparticles, the percentage recoveries were $99.8 \%, 51.8 \%$ and $80.4 \%$ for $\mathrm{Au}(\mathrm{III}), \mathrm{Pt}(\mathrm{IV})$ and $\mathrm{Pd}(\mathrm{II})$, respectively. Lastly the percentage recoveries decreased 


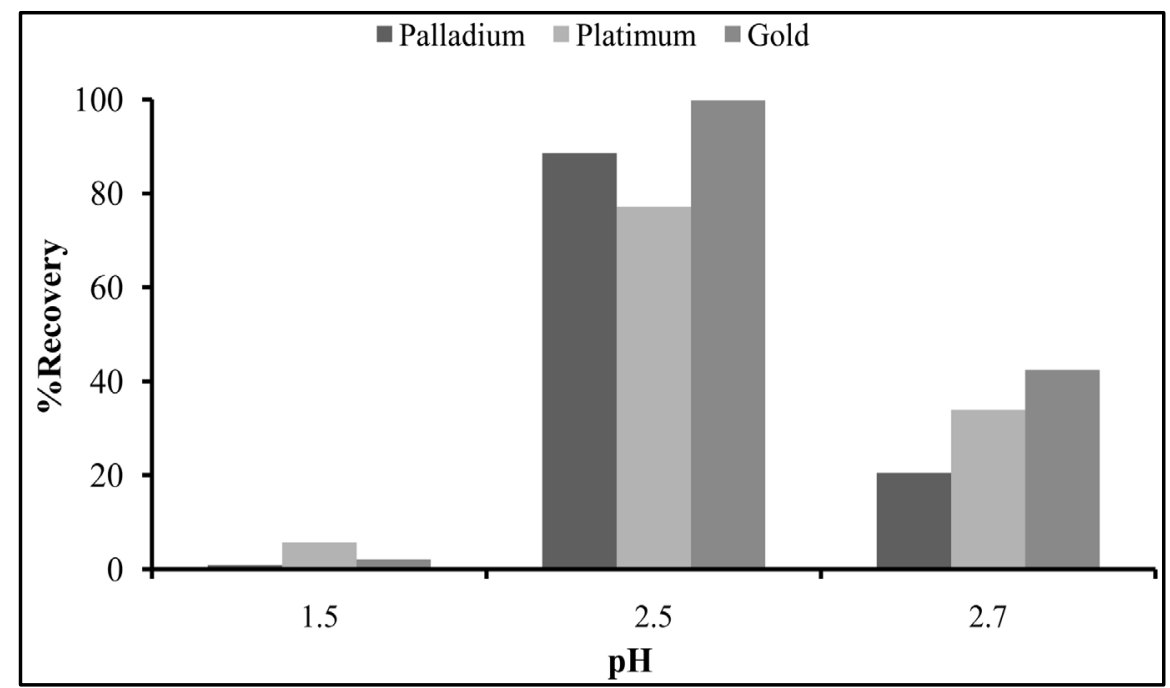

Figure 7. Recovery of precious metal ions at $10 \mathrm{mg} \cdot \mathrm{L}^{-1}$ using $0.065 \mathrm{~g}$ modified iron oxide nanoparticles at different $\mathrm{pH}$ values.

to $42.5 \%, 33.9 \%$ and $20.5 \%$ for $\mathrm{Au}(\mathrm{III}), \mathrm{Pt}(\mathrm{IV})$ and $\mathrm{Pd}(\mathrm{II})$, respectively, at $\mathrm{pH}$ 2.7. On the other hand, unmodified magnetic iron oxide nanoparticles gave recoveries of $36.2 \%, 33.9 \%$ and $0.7 \%$ for $\mathrm{Au}(\mathrm{III}), \mathrm{Pt}(\mathrm{IV})$ and $\mathrm{Pd}(\mathrm{II})$, respectively. A study by Ju et al. [48] using a red alga, Galdieria sulphuraria also recovered gold and palladium precious metals ions with high efficiency at $\mathrm{pH} 2.5$. The adsorption capacity tends to decrease with increase in $\mathrm{pH}$ because at a high $\mathrm{pH}$; there might be less absorption of metal ions due to decreasing chloride anions from the metal salts [46]. On the other hand, at a $\mathrm{pH}$ of 1.5 the competition between positively charged hydrogen and precious metal ions might be higher therefore resulting in the lower recoveries observed [34].

At low $\mathrm{pH}$, the dominant species of the PGMs are $\mathrm{AuCl}_{4}^{-}, \mathrm{PtCl}_{6}^{2-}$ and $\mathrm{PdCl}_{4}^{-}$[49] and the zeta potential measurements confirm that the surface of modified and unmodified magnetite particles are positively charged in acidic $\mathrm{pH}$ region which actually coincides with $\mathrm{pH}$ range below point of zero charge. This promotes a favorable environment for electrostatic adsorption of $\mathrm{AuCl}_{4}^{-}$, $\mathrm{PtCl}_{6}^{2-}$ and $\mathrm{PdCl}_{4}^{-}$ions. According to Homchuen et al. [49], at highly acidic $\mathrm{pH}$, the dissolution of $\mathrm{Fe}^{3+}$ is promoted generating ions that compete with $\mathrm{AuCl}_{4}^{-}$complex for electrons in active sites of the surface of magnetite. The interaction between $\mathrm{AuCl}_{4}^{-}$ions and the magnetite surface through physical adsorption stimulated active sites for electron transfer necessary for the reduction of gold chloride complexes to elemental gold. This may explain why modified iron oxide recovered more PGMs than the unmodified magnetite although the later was more positively charged at low $\mathrm{pH}$. The small uptake of PGMs by the unmodified iron oxide could be due to the presence pf the $\mathrm{Fe}^{3+}$ dissolved from magnetite, a process that is somehow inhibited in the case modified magnetite. The presence $\mathrm{Fe}^{3+}$ as an oxidizer competes with $\mathrm{Au}(\mathrm{III}), \mathrm{Pt}(\mathrm{IV})$ and $\mathrm{Pd}(\mathrm{II})$ on the surface of magnetite. 


\subsubsection{Effect of Initial Adsorbate Concentration}

Several studies have demonstrated that initial adsorbate concentration plays a role in the adsorption process of metal ions [35] [39] [40] [47]. Figure 8 shows the effect of initial adsorbate concentration as varied from 10 to $100 \mathrm{mg} \cdot \mathrm{L}^{-1}$ using modified magnetic iron oxide nanoparticles at constant $\mathrm{pH}$ (2.5), agitation time of two hours, and $0.065 \mathrm{~g}$ dosage. As initial adsorbate concentration increased, recovery decreased from $83.2 \%$ to $42.3 \%$ for $\mathrm{Au}(\mathrm{III}), 49.7 \%$ to $32.0 \%$ for $\mathrm{Pt}(\mathrm{IV})$, and $40.9 \%$ to $35.1 \%$ for $\mathrm{Pd}(\mathrm{II})$. In comparison to unmodified magnetic iron oxide, nanoparticles percentage recoveries varied from $60.2 \%$ to $43.3 \%$ for $\mathrm{Au}(\mathrm{III}), 4.1 \%$ to $26.8 \%$ for $\mathrm{Pt}(\mathrm{IV})$ and 91.4 to $62.4 \%$ for $\mathrm{Pd}(\mathrm{II})$. This implies that low initial adsorbate concentration increases the ratio of available sites on the surface of adsorbent to the adsorbate concentration thus higher recovery percentage [36] [49]. The opposite is true when initial concentrations are higher. However, Obuseng et al. [34] varied initial adsorbate concentration from 1 to 14 $\mathrm{mg} \cdot \mathrm{L}^{-1}$ and the results showed that as the initial adsorbate concentration rises, the recovery percentage of metal ions rise until an optimal concentration where biomass is saturated is achieved after which a steady decline is detected when the initial adsorbate concentration is increased. Maina et al. [35] concur with these findings. The current study therefore suggest that the initial adsorbate concentration considered could have been toward the optimal concentration thus a decline in recovery percentage of precious metal ions when the initial adsorbate concentration was increased.

\subsubsection{Effect of Agitation Time}

The effect of agitation time on adsorption of precious metal ions using modified magnetic iron oxide nanoparticles was studied between $0-240$ minutes at constant $\mathrm{pH}$ (2.5), initial adsorbate concentration of $10 \mathrm{mg} \cdot \mathrm{L}^{-1}$, agitation time of two hours, and $0.065 \mathrm{~g}$ dosage. Figure 9 depicts that the percentage recoveries both increased and decreased within the first 120 minutes after which percentage

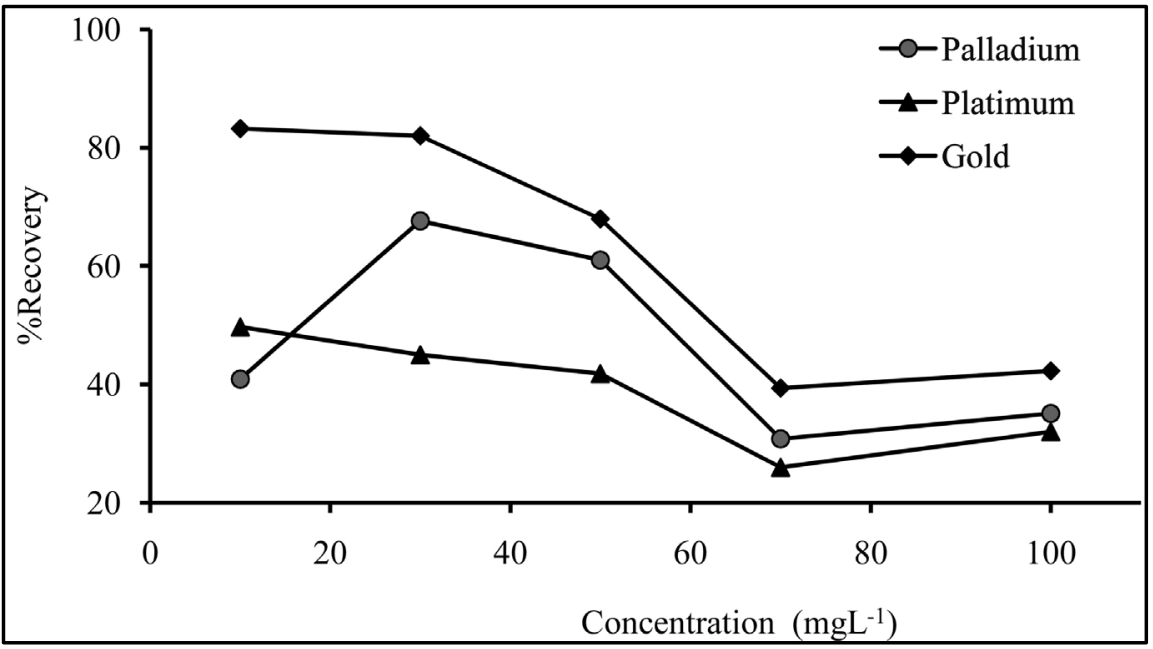

Figure 8. Effect of initial concentration on the recovery of precious metal ions using modified nanoparticles at $10-100 \mathrm{mg} \cdot \mathrm{L}^{-1}$. 


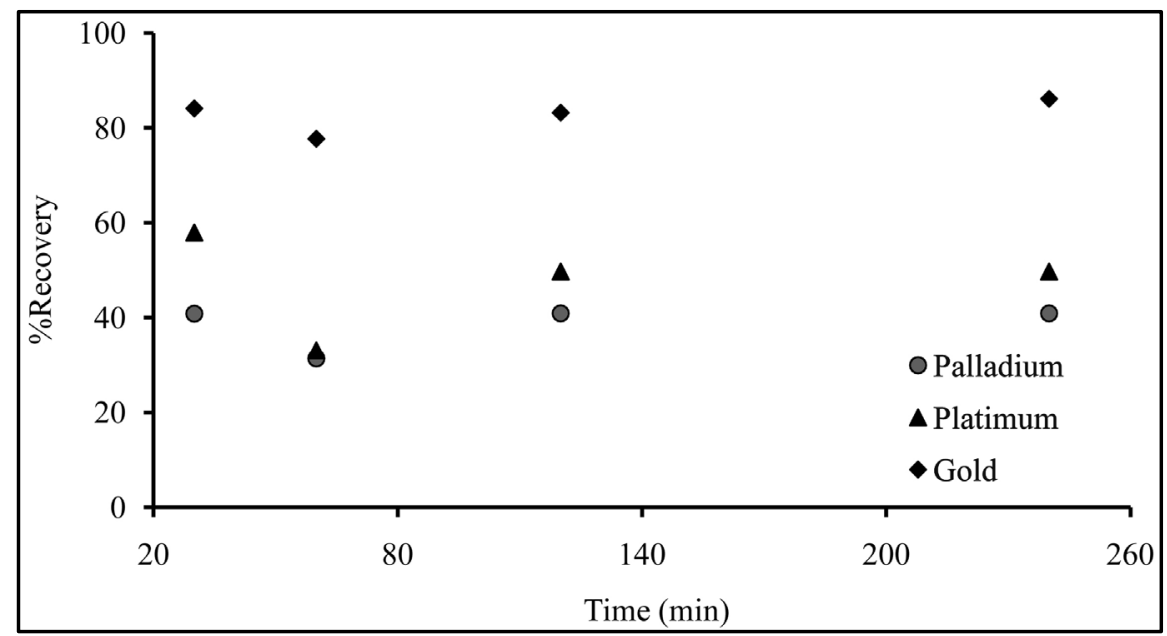

Figure 9. Effect of agitation time on recovery of precious metal ions using modified nanoparticles between 0 - 240 minutes.

recoveries remain almost constant or just slightly increased. The equilibrium was, therefore, reached in 120 minutes. Similar results were attained with unmodified magnetic iron oxide nanoparticles. Studies by Padmavathy et al. [40] and Candice et al. [50] on similar adsorbent materials also concur with adsorption equilibrium of 120 minutes. These studies suggest that during the initial stages of adsorption there are more vacant sites on the surface of the adsorbent resulting in higher percentage recoveries of precious metals ions and these tend to get saturated at equilibrium thus declined adsorption rate.

\subsubsection{Effect of Adsorbent Dosage}

The effect of adsorbent dosage on adsorption of precious metal ions using modified magnetic iron oxide nanoparticles was studied between $0.005 \mathrm{~g}$ to $0.085 \mathrm{~g}$, equilibrated for two hours with $10 \mathrm{mg} \cdot \mathrm{L}^{-1}$ at $\mathrm{pH}$ 2.5. As shown in Figure 10, precious metals ions recoveries rise with dosage until $0.065 \mathrm{~g}$ optimal dosage is attained after which a decline in percentage recoveries was obtained. At the optimal dosage, maximal recovery of $99.8 \% \mathrm{Au}(\mathrm{III})$ was obtained followed by 87.7\% $\mathrm{Pt}(\mathrm{IV})$ and then $72.7 \% \mathrm{Pd}(\mathrm{II})$.Comparisons with unmodified magnetic iron oxide nanoparticles yielded percentage recoveries of $100 \% \mathrm{Au}(\mathrm{III}), 88.1 \%$ $\mathrm{Pt}(\mathrm{IV})$ and 67.3\% Pt(IV). Studies by Mavhungu et al. [46] and Hariani et al. [47] obtained similar results. These studies demonstrate that increase in percentage recoveries with increase in adsorbent dosage result from rise in vacant active sites on the adsorbent surface. Another study by Maina et al. [35] explained further that increase in percentage recoveries with increase in adsorbent dosage is observed until an optimal adsorption level is attained after which the percentage recoveries are reduced due to the decline in vacant active sites on the surface of the adsorbent.

\section{Conclusion}

In this study, the effectiveness of modified magnetic iron oxide nanoparticles in 


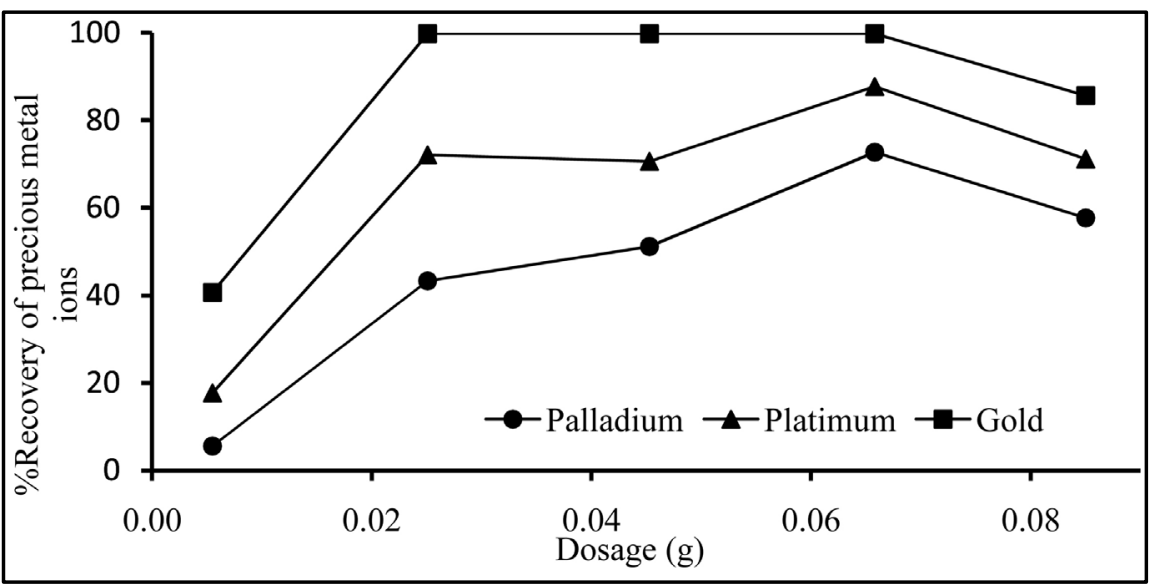

Figure 10. Recovery of precious metal ions at $10 \mathrm{mg} \cdot \mathrm{L}^{-1}$ using different dosages of modified nanoparticles.

recovery of $\mathrm{Au}(\mathrm{III}), \mathrm{Pt}(\mathrm{IV})$ and $\mathrm{Pd}(\mathrm{II})$ precious metal ions from aqueous solutions was investigated. The nanoparticles were prepared by chemical co-precipitation of $\mathrm{Fe}^{3+}$ and $\mathrm{Fe}^{2+}(2: 1)$ in aqueous protein solution (1\%) extracted from $M$. oleifera seed. The parameters that studied the adsorption behaviour of the precious metal ions on the nanoparticles on a laboratory scale were $\mathrm{pH}$, initial adsorbate concentration, agitation time and adsorbent dosage. Various characterization techniques namely, FTIR, SEM,TGA, and zeta potential were applied to assess diverse functional groups responsible for adsorption, morphology, thermal stability, and surface charge of the nanoparticles. The FTIR confirmed various functional groups such as amine/amide, carbonyl, hydroxyl, carboxylic and iron oxide on modified magnetic iron oxide nanoparticles that could be responsible for selective recovery of precious metal ions. SEM depicted porous morphology with various pore sizes that might be responsible for retention of precious metal ions. TGA showed a slow weight loss of about $17.2 \%$ suggesting stability for the nanoparticles. The isoelectric (point of zero charge) for modified iron oxide nanoparticles was around 3.69, thus the dependency of adsorption on $\mathrm{pH}$ and recovery of precious metal ions could be explained by the surface charge values obtained. The optimal conditions for recovery of the precious metal ions obtained from the study were: $\mathrm{pH} 2.5 ; 120$ minutes agitation time; $10 \mathrm{mg} \cdot \mathrm{L}^{-1}$ initial concentration; adsorbent dosage $0.065 \mathrm{~g}$. At these conditions, maximum recoveries of $99.8 \% \mathrm{Au}(\mathrm{III}), 87.7 \% \mathrm{Pt}(\mathrm{IV})$, and $72.7 \% \mathrm{Pd}(\mathrm{II})$ were obtained. The results obtained in the study therefore suggest that modified magnetic iron oxide could be effective in recovery of $\mathrm{Au}(\mathrm{III}), \mathrm{Pt}(\mathrm{IV})$ and $\mathrm{Pd}(\mathrm{II})$ precious metal ions. The results clearly show that the recovery of precious metals is not solely due to electrostatic interactions, otherwise the recoveries would have been high for unmodified iron oxide system since it is more positive at low $\mathrm{pH}$ as observed from zeta potential measurements. Further studies are needed to determine the mechanism for precious metals recovery by iron oxide nanoparticles modified with Moringa seed proteins. 


\section{Acknowledgements}

The authors kindly acknowledge the four universities namely Namibia University of Science and Technology (NUST), University of Namibia (UNAM), The University of South Africa (UNISA) and The University of the Witwatersrand (WITS) for the resources supplied for this work.

\section{Conflicts of Interest}

None.

\section{References}

[1] Umeda, H., Sasaki, A., Takahashi, K., Haga, K., Takasaki, Y. and Sibayama, A. (2011)) Recovery and Concentration of Precious Metals from Strong Acidic Wastewater. Materials Transactions, 52, 1462-1470. https://doi.org/10.2320/matertrans.M2010432

[2] Ju, X., Igaraschi, K., Miyashita, S., Mitsuhashi, H., Inagaki, K., Fuji, S., Sawada, H., Kuwabara, T. and Minoda, A. (2016) Effective and Selective Recovery of Gold and Palladium Ions from Metal Wastewater Using a Sulfothermophilic Red Alga, Galdieria sulphuraria. Bioresource Technology, 211, 759-764. https://doi.org/10.1016/j.biortech.2016.01.061

[3] Nikoloski, A.N. and Ang, K.L. (2014) Review of the Application of Ion Exchange Resins for the Recovery of Platinum-Group Metals from Hydrochloric Acid Solutions. Mineral Processing and Extractive Metallurgy Review, 35, 369-389. https://doi.org/10.1080/08827508.2013.764875

[4] Kulkarni, S.J. (2016) Removal and Recovery of Platinum: An Insight into Studies and Research. International Journal of Research \& Review, 3, 74-77.

[5] He, J. and Kappler, A. (2017) Recovery of Precious Metals from Waste Streams. Microbial Biotechnology, 10, 1194-1198. https://doi.org/10.1111/1751-7915.12759

[6] Aghaei, E., Alorro, R.D., Encila, A.N. and Yoo, K. (2017) Review: Magnetic Adsorbents for the Recovery of Precious Metals from Leach Solutions and Wastewater. Metals-Open Access Metallurgy Journal, 7, 529.

[7] Reith, F., Campbell, S.G., Ball, A.S., Pring, A. and Southam, G. (2014) Platinum in Earth Surface Environments. Earth-Science Reviews, 131, 1-21.

https://doi.org/10.1016/j.earscirev.2014.01.003

[8] Kavitha, V. (2014) Extraction of Precious Metals from e-Waste. Journal of Chemical and Pharmaceutical Sciences, 3, 147-149.

[9] Sharma, S., Kumar, A.K.S. and Rajesh, N. (2017) Review: A Perspective on Diverse Adsorbent Materials to Recover Precious Palladium and the Way Forward. The Royal Society of Chemistry, 7, 52133-52142.

[10] Yahorava, V. and Kotze, M. (2014) Ion Exchange Technology for the Efficient Recovery of Precious Metals from Waste and Low-Grade Streams. Journal of the Southern African Institute of Mining and Metallurgy, 114, 173-181.

[11] Giraldo, L., Erto, A. and Moreno-Pirajan, J.C. (2013) Magnetite Nanoparticles for Removal of Heavy Metals from Aqueous Solutions: Synthesis and Characterization. Adsorption Science \& Technology, 19, 465-474.

https://doi.org/10.1007/s10450-012-9468-1

[12] Al-Sand, K.A., Amr, M.A., Hadi, D.T., Arar, R.S., Al Suloiti, M.M., Abdul Malik, T.A., Alsahamary, N.M. and Kwak, J.C. (2012) Iron Oxide Nanoparticles: Applica- 
bility for Heavy Metal Removal from Contaminated Water. Arab Journal of Nuclear Sciences and Applications, 45, 335-346.

[13] Neyaz, N., Siddiqui, W.A. and Nair, K.K. (2014) Application of Surface Functionalized Iron Oxide Nanomaterials as a Nanosorbents in Extraction of Toxic Heavy Metals from Groundwater: A Review. International Journal of Environmental Sciences, 4, 472-483.

[14] Ali, I. (2012) New Generation Adsorbents for Water Treatment. Chemical Reviews, 112, 5073-5091. https://doi.org/10.1021/cr300133d

[15] Xu, J., Sun, J., Wang, Y., Sheng, J., Wang, F. and Sun, M. (2014) Application of Iron Magnetic Nanoparticles in Protein Immobilization. Molecules, 19, 11465-11486. https://doi.org/10.3390/molecules190811465

[16] Okoli, C.C. (2012) Development of Protein-Functionalized Magnetic Iron Oxide Nanoparticles; Potential Application in Water Treatment. University Service Stockholm, Stockholm.

[17] Tang, C.N. and Lo, I.M. (2013) Magnetic Nanoparticles: Essential Factors for Sustainable Environmental Applications. Water Research, 47, 2613-2632. https://doi.org/10.1016/j.watres.2013.02.039

[18] Wu, W., Wu, Z., Yu, T., Jiang, C. and Kim, W. (2015) Recent Progress on Magnetic Iron Oxide Nanoparticles: Synthesis, Surface Functional Strategies, and Biomedical Applications: A Review. Science and Technology of Advanced Materials, 16, 43. https://doi.org/10.1088/1468-6996/16/2/023501

[19] Tombacz, E., Farkas, K., Foldesi, I., Szekeres, M., Illes, E., Toth, I.Y., Nesztor, D. and Szabo, T. (2016) Polyelectrolyte Coating on Supermagnetic Iron Oxide Nanoparticles as Interface between Magnetic Core and Bio Relevant Media. Interface Focus, 6, 1-8. https://doi.org/10.1098/rsfs.2016.0068

[20] Yang, X.C., Shang, Y.L., Li, Y.H., Zhai, J., Foster, N.R., Li, Y.X., Zou, D. and Pu, Y. (2014) Synthesis of Monodisperse Iron Oxide Nanoparticles without Surfactants. Journal of Nanomaterials, 1-6. https://doi.org/10.1155/2014/740856

[21] Ehrampoush, M.H., Miria, M., Salmani, M.H. and Mahvi, A.H. (2015) Cadmium Removal from Aqueous Solution by Green Synthesis Iron Oxide Nanoparticles with Tangerine Peel Extract. Journal of Environmental Health Science and Engineering, 13, 1-7. https://doi.org/10.1186/s40201-015-0237-4

[22] Lakshmanam, R. (2013) Application of Magnetic Nanoparticles and Reactive Filter Materials for Wastewater Treatment. Royal Institute of Technology, Stockholm.

[23] Gill, S.K., Singh, G. and Khatri, M. (2017) Synthesis and Characterization of Superparamagnetic Iron Oxide Nanoparticles for Water Purification Applications. International Journal of Engineering, Science and Technology, 4, 355-359.

[24] Remya, N.S., Syama, S., Sabareeswaran, A. and Mohanan, P.V. (2016) Safety of Iron Oxide Nanoparticles-A Regulatory Perspective. International Journal of Pharmaceutics, 1-2.

[25] Paik, S.Y.R., Kim, J.S., Shin, S.J. and Ko, S. (2015) Characterization, Quantification and Determination of the Toxicity of Iron Oxide Nanoparticles to the Bone Marrow Cells. International Journal of Molecular Sciences, 16, 22243-22257. https://doi.org/10.3390/ijms160922243

[26] Vasylkiv, O., Bezdorozhev, O. and Sakka, Y. (2016) Synthesis of Iron Oxide Nanoparticles with Different Morphologies by Precipitation Method with and without Chitosan Addition. Journal of the Ceramic Society of Japan, 124, 489-494. https://doi.org/10.2109/jcersj2.15288 
[27] Gutierrez, A.M., Dziubla, T.D. and Hilt, J.Z. (2017) Recent Advances on Iron Oxide Magnetic Nanoparticles as Sorbents of Organic Pollutants in Water and Wastewater Treatment: Review. Reviews on Environmental Health, 32, 111-117. https://doi.org/10.1515/reveh-2016-0063

[28] Maikokera, R. and Kwaambwa, H.M. (2007) Interfacial Properties and Fluorescence of a Coagulating Protein Extracted from Moringa oleifera Seeds and Its Interaction with Sodium Dodecyl Sulphate. Colloids and Surfaces B, 55, 173-178.

[29] Shan, T.C., Al Matar, M., Makky, E.A. and Ali, E.N. (2017) The Use of Moringa oleifera Seed as a Natural Coagulant for Wastewater Treatment and Heavy Metals Removal. Applied Water Science, 7, 1369-1376.

https://doi.org/10.1007/s13201-016-0499-8

[30] Kebede, T.M., et al. (2018) Study on Adsorption of Some Common Metal Ions Present in Industrial Effluents by Moringastenopetala Seed Powder. Journal of Environmental Chemical Engineering, 6, 1378-1389.

https://doi.org/10.1016/j.jece.2018.01.012

[31] Idris, M.N., Jami, M.S., Hammed, A.M. and Jamal, P. (2016) Moringa oleifera Seed Extract: A Review on Its Environmental Applications. International Journal of Applied Environmental Sciences, 11, 1469-1486.

[32] Kazemzadeh, H., Ataie, A. and Rashchi, F. (2012) Synthesis of Magnetic Nanoparticles by Reverse Co-Precipitation. International Journal of Modern Physics: Conference Series, 5, 160-167. https://doi.org/10.1142/S2010194512001973

[33] Witek-Krowiak, A. (2013) Application of Beech Sawdust for Removal of Heavy Metals from Water: Bisorption and Desorption Studies. European Journal of Wood and Wood Products, 71, 227-236. https://doi.org/10.1007/s00107-013-0673-8

[34] Obuseng, V., Nareetsile, F. and Kwaambwa, H.M. (2012) A Study of the Removal of Heavy Metals from Aqueous Solutions by Moringa oleifera Seeds and Amine-Based Ligand 1,4-bis[N, N-bis(2-picoyl) amino)butane]. Analytica Chimica Acta, 730, 87-92. https://doi.org/10.1016/j.aca.2012.01.054

[35] Maina, I.W., Obuseng, V. and Nareetsile, F. (2016) Use of Moringa oleifera (Moringa) Seed Pods and Sclerocarya birrea (Morula) Nut Shells for Removal of Heavy Metals from Waste Water and Borehole Water. Journal of Chemistry, 2016, Article ID: 9312952. https://doi.org/10.1155/2016/9312952

[36] Araujo, C.S.T., Alves, V.N., Rezend, H.C., Almeida, I.L.S., de Assuncao, R.M.N., Tarley, C.R.T., Segatelli, M.G. and Coelho, N.M.M. (2010) Characterization and Use of Moringa oleifera Seeds as Biosorbent for Removing Metal Ions from Aqueous Effluents. Water Science \& Technology, 62, 2198-2203.

https://doi.org/10.2166/wst.2010.419

[37] Nermark, F.M. (2014) Bioremediation of Copper and Lead Contaminated Soil Using Moringa oleifera Seeds Water Extract and Physicochemical Studies. MSc Dissertation, University of Botswana, Gaborone.

[38] Ramavandi, B., Hashemi, S. and Kafaei, R. (2015) A Novel Method for Extraction of a Proteinous Coagulant from Plantago ovata Seeds for Water Treatment Purposes. Methods X, 2, 278-282. https://doi.org/10.1016/j.mex.2015.05.006

[39] Kandpal, N.D., Sah, N., Loshali, R., Joshi, R. and Prasad, J. (2014) Co-Precipitation Method of Synthesis and Characterization of Iron Oxide Nanoparticles. Journal of Scientific \& Industrial Research, 73, 87-90.

[40] Padmavathy, K.M., Madhu, G. and Haseena, P.V. (2016) A Study on the Effects of $\mathrm{pH}$, Adsorbent Dosage, Time, Initial Concentration and Adsorption Isotherm Study for the Removal of Hexavalent Chromium (Cr (IV)) from Wastewater by Magnetite 
Nanoparticles. Procedia Technology, 24, 585-594.

https://doi.org/10.1016/j.protcy.2016.05.127

[41] Nethaji, S., Sivasamy, A. and Mandal, A.B. (2013) Adsorption Isotherms, Kinetics and Mechanism for the Adsorption of Cationic and Anionic Dyes onto Carbonaceous Particles Prepared from Juglans regia Shell Biomass. International Journal of Environmental Science and Technology, 10, 231-242.

https://doi.org/10.1007/s13762-012-0112-0

[42] Rajput, S., Pittman, C.U. and Mohan, J.D. (2016) Magnetic Magnetite $\left(\mathrm{Fe}_{3} \mathrm{O}_{4}\right)$ Nanoparticles Synthesis and Application for Lead $\left(\mathrm{Pb}^{2+}\right)$ and Chromium $\left(\mathrm{Cr}^{6+}\right)$ Removal from Water. Journal of Colloid and Interface Science, 468, 334-346. https://doi.org/10.1016/j.jcis.2015.12.008

[43] Mahdari, M., Namvar, F., Ahmad, M.B. and Mohamad, R. (2013) Green Biosynthesis and Characterisation of Magnetic Iron Oxide $\left(\mathrm{Fe}_{3} \mathrm{O}_{4}\right)$ Nanoparticles Using Seaweed (Sargassum muticum) Aqueous Extract. Molecules, 18, 5954-5964. https://doi.org/10.3390/molecules18055954

[44] Ramsden, E.N. (1996) A-Level Chemistry Detection and Analysis. Stanely Thormes Publishers Ltd., 72-73.

[45] Sneha, M. and Sundaram, N.M. (2015) Preparation and Characterization of an Iron Oxide-Hydroxyapatite Nanocomposite for Potential Bone Cancer Therapy. International Journal of Nanomedicine, 10, 99-106.

[46] Mavhungu, A., Mbaya, R.K.K. and Moropeng, M.L. (2013) Recovery of Platinum and Palladium Ions from Aqueous Solution Using Grape Stalk Waste. International Journal of Chemical Engineering and Application, 4, 1-5.

[47] Hariani, P.L., Faizal, M., Ridwan, M. and Setiabudidaya, D. (2013) Synthesis and Properties of $\mathrm{Fe}_{3} \mathrm{O}_{4}$ Nanoparticles by Co-Precipitation Method to Removal Procion Dye. International Journal of Environmental Science and Development, 4, 336-340. https://doi.org/10.7763/IJESD.2013.V4.366

[48] Ju, X., Igarashi, K., Miyashita, S., Mitsuhashi, H., Inagaki, K., Fuji, S., Sawada, H., Kuwabara, T. and Minoda, A. (2016) Effective and Selective Recovery of Gold and Palladium Ions from Metal Wastewater Using a Sulfothermophilic Red Alga, Galdieria sulphuraria. Bioresource Technology, 211, 759-764.

https://doi.org/10.1016/j.biortech.2016.01.061

[49] Homchuen, P., Alolrro, R.D., Hiyoyoshi, N., Sato, R., Kitjitani, H. and Ito, M. (2016) A Study on the Utilization of Magnetitie for the Recovery of Platinum Group Metals from Chloride Solution. Mineral Processing and Extractive Metallurgy Review, 37, 246-254. https://doi.org/10.1080/08827508.2016.1181629

[50] Candice, C.T., Kandawa-Schulz, M., Amuanyena, M. and Kwaambwa, H.M. (2017) Adsorptive Removal Aqueous Solution of Cr (IV) by Green Moringa Tea Leaves Biomass. Journal of Encapsulation and Adsorption Sciences, 7, 108-119. 